\title{
Family and partner interpersonal violence among American Indians/Alaska Natives
}

\author{
Katherine J Sapra ${ }^{1 *+}$, Sarah M Jubinski ${ }^{2+}$, Mina F Tanaka ${ }^{3+}$ and Robyn RM Gershon ${ }^{4,5}$
}

\begin{abstract}
Family and partner interpersonal violence are common among American Indian/Alaska Native (Al/AN) populations. Al/AN women have the second highest prevalence of violence against women among all racial/ethnic groups in the United States, and child abuse prevalence rates in Al/AN populations are among the highest. Elder abuse in Al/AN is also an important concern, although data on this are sparse. This review describes the epidemiology of child abuse, violence against women, and elder abuse among Al/AN, including prevalence and associated risk factors. The authors discuss potential reasons for the high burden of interpersonal violence among Al/AN, including common risk factors. Important limitations in existing literature are also highlighted, along with recommendations for future research on this topic.
\end{abstract}

Keywords: American Indians/Alaska Natives; Native Americans; Child abuse; Child neglect; Elder abuse; Domestic violence; Sexual assault; Violence against women; Rape

\section{Introduction}

In comparison to other races/ethnicities, American Indians/Alaska Natives (AI/AN) have higher rates of interpersonal violence. Child abuse, violence against women (VAW), and elder abuse are important contributors to the increased risk of morbidity and mortality among AI/AN. In this article, we present an overview of the prevalence and risk factors for family and partner interpersonal violence in AI/AN living in the United States and discuss research gaps, with recommendations for future research directions.

The World Health Organization defines interpersonal violence as "the intentional use of physical force or power, threatened or actual, against another person that either results in or has a high likelihood of resulting in injury, death, psychological harm, maldevelopment or deprivation (World Health Organization 2002)." Interpersonal violence is subdivided into family/partner (related individuals) and community (unrelated individuals) violence. This paper focuses on the former, which includes child, intimate partner, and elder abuse (World Health Organization 2002), and also touches upon community violence of a sexual nature (e.g., rape by acquaintances and strangers).

\footnotetext{
* Correspondence: kjh2127@columbia.edu

${ }^{\dagger}$ Equal contributors

${ }^{1}$ Department of Epidemiology, Mailman School of Public Health, Columbia University, 722 W. 168th St, New York, NY 10032, USA

Full list of author information is available at the end of the article
}

Multiple small-scale studies and national surveys have demonstrated a higher prevalence of interpersonal violence among AI/AN populations compared to the general U.S. population. Child abuse and neglect and VAW are alarmingly high. Child abuse and neglect prevalence in AI/AN communities are among the highest of any racial/ethnic group, and VAW affects the majority of AI/AN women. Elder abuse is a concern for AI/AN tribal leaders, though it is not well-characterized.

As in other populations, obtaining accurate prevalence data can be challenging. While some population-based studies among AI/AN living on reservations have been conducted (Harwell et al. 2003; Manson et al. 2005), much of the existing literature on interpersonal violence among AI/AN relies on existing data sources, particularly records from law enforcement, governmental agencies, and health care services. Only those who report abuse to police or seek medical care for injuries are included, and victims may be hesitant to report crimes due to shame and fear of retaliation. Furthermore, overlapping and conflicting jurisdictions between tribal, state, federal authorities impede reporting of abuse and neglect (Cross and Simmons 2008). State reporting requirements typically do not extend to AI/AN living on tribal lands, and Fox (2003) estimates that only about $42-61 \%$ of AI/AN child abuse cases reach federal reporting systems. These obstacles are further complicated by inconsistent definitions of abuse and 
record-keeping for $\mathrm{AI} / \mathrm{AN}$, and a lack of resources for tribal workers responsible for reporting cases. Estimating the prevalence of interpersonal violence from existing data sources is made more difficult as tribal nations do not have jurisdiction over non-AI/AN (Deer 2004) and 70\% of violent crime against $\mathrm{AI} / \mathrm{AN}$ is perpetrated by non-AI/AN (Greenfeld and Smith 1999).

Valid prevalence estimates depend upon accurate numerators (number of cases) and denominators (population at risk). The challenges in reporting described above contribute to inaccurate prevalence estimates, as the numerator obtained from these sources will be artificially low. These methods of case ascertainment may also introduce selection bias as victims who reach the attention of service providers may have different risk factor profiles than those who do not. While these limitations are not unique to studies among $\mathrm{AI} / \mathrm{AN}$, they remain an impediment to our understanding of the burden of interpersonal violence in this population.

The studies reviewed in this article fall into either of two categories: cross-sectional surveys and ethnographic studies, generally with data collected fromretrospective selfreporting or review of records. Due to the absence of longitudinal studies, incidence rates of interpersonal violence in $\mathrm{AI} / \mathrm{AN}$ cannot at this time be ascertained or compared between subpopulations.

It is believed that the historic maltreatment of $\mathrm{AI} / \mathrm{AN}$ and the transmission of these historical injuries through generations contribute to the high prevalence of interpersonal violence among AI/AN (Brave Heart 1998). Early annihilation efforts by the U.S. government, including warfare and purposeful spread of infectious diseases (DeBruyn et al. 2001), were followed by assimilation efforts through placement of AI/AN children in boarding schools and urban relocation programs (Bell and Lim 2005; Brave Heart 1998). Assimilation efforts also may have led to loss of culture and traditions, resulting in increased prevalence of dysfunctional family life and mental disorders, which are additional risk factors for interpersonal violence (Brave Heart 1998; Duran et al. 2009; Duran and Duran 1995; Pavkov et al. 2010). In the case of boarding schools, traditional familial and parenting models were dissolved and replaced with institutional care, which often modeled negative behaviors, such as abuse and neglect.

Scholars have suggested that historical trauma contributes to interpersonal violence in $\mathrm{AI} / \mathrm{AN}$ populations through several mechanisms. Brave Heart (2003) posits that many AI/AN turned to alcohol and other substances as a coping mechanism. Increased substance use may thus serve as a link between historical trauma and violence (Arbuckle et al. 1996; Berlin 1987; DeBruyn et al. 1992; Horejsi et al. 1992; King 1999; Luna-Firebaugh 2006; Nelson et al. 1996; Piasecki et al. 1989; Robin et al. 1998).

\section{Review}

\section{Prevalence of child abuse}

While no standard definition of child maltreatment is used by all reporting and researching entities (Earle and Cross 2001), under federal law, child abuse and neglect are defined as, "any recent act or failure to act on the part of a parent or caretaker, which results in death, serious physical or emotional harm, sexual abuse or exploitation, or an act or failure to act which presents an imminent risk of serious harm" (Child Abuse Prevention and Treatment Act 2013, p. 6). The per capita rate of substantiated report of child abuse and neglect for AI/AN children 14 years or younger is one for every 30 children, compared to one for every 58 in the general population (Fox 2003). Nationally, AI/AN children have higher rates of reported abuse and neglect than their white counterparts, but have similar or lower rates compared to African American children (U.S. Department of Health and Human Services 2010). However, one analysis of data from Department of Health and Human Services' National Child Abuse and Neglect Data System (NCANDS) found lower rates of physical and sexual abuse in AI/AN children than in non-Hispanic White children (Earle and Cross 2001). This observation is in discrepancy with findings from other studies, but may be due to underreporting, as $\mathrm{AI} / \mathrm{AN}$ abuse cases investigated by tribal law enforcement or the Federal Bureau of Investigations are not always reported to NCANDS. Using child death review board files, Welch and Bonner (2013) studied patterns of fatal child neglect in Oklahoma over 22 years. AI/AN children were disproportionately represented in the sample of deaths, with most due to supervisory/ environmental neglect leading to unintentional drowning and smoke inhalation. While AI/AN accounted for approximately $9 \%$ of Oklahoma's population, $\mathrm{AI} / \mathrm{AN}$ children represented $13 \%$ of victims of fatal neglect.

Data from national surveys also document higher rates of physical abuse in AI/AN as compared to the general population. The National Survey of Adolescents determined that lifetime prevalence of childhood physical abuse among $\mathrm{AI} / \mathrm{AN}$ youth is $15 \%$, second only to African-American youth at $16 \%$ (Hanson et al. 2006) (Table 1). Hawkins et al.'s (2010) national survey of 12 to 17-year-olds found a similar prevalence of child physical abuse in AI/AN and African Americans (15\%).

Studies using non-national sampling frames suggest that rates of child abuse and neglect may be higher than officially reported or captured in national surveys. In a cross-sectional study of $234 \mathrm{AI} / \mathrm{AN}$ women at an Indian Health Service (IHS) outpatient clinic, $77 \%$ of respondents reported some type of childhood abuse or neglect (Duran et al. 2004). Neglect was the most common maltreatment in this sample, with $63 \%$ experiencing physical and/or emotional neglect. The study found that women reporting neglect were also much more likely to have experienced 
Table 1 Prevalence of childhood abuse and neglect in American Indians/Alaska natives, by year of study

First author year

Lodico et al. 1996

Robin et al. 1997

Saewyc et al. 2003

Duran et al. 2004

Libby et al. 2005

Population and data source

$9^{\text {th }}$ and $12^{\text {th }}$ grade students of a

Midwestern state; $10 \%$ random

sample of all white, African American,

and $\mathrm{Al} / \mathrm{AN}$ respondents with

anonymous self-report survey

of risk behaviors

Southwestern tribe; enrolled tribal members over age 21; semi-structured psychiatric interview

2 cohorts $(1992,1998)$ of $9^{\text {th }}$ and $12^{\text {th }}$ graders in Minnesota public schools completing state-wide anonymous self-report survey of risk behavior

Outpatient primary care clinic at community-based Indian Health Hospital in Albuquerque, clinic-based sampling with self-report survey

Southwestern tribe and 2 closely affiliated Northern plains tribes; stratified random sampling of tribal rolls computer-assisted in-person interviews

Sample size
$494 \mathrm{Al} / \mathrm{AN}$ adolescer

582 Al/AN adults
$\geq 21$ years of age

1992: $750 \mathrm{Al} / \mathrm{AN}$ adolescents

1998: $548 \mathrm{Al} / \mathrm{AN}$ adolescents

Southwest tribe

1,446 Southwest tribal members age 15-54

$234 \mathrm{Al} / \mathrm{AN}$ women age 18-45

\section{Measure}

Lifetime sexual abuse by family

Lifetime sexual abuse by

nonfamily members

Lifetime sexual abuse by both family and nonfamily members

Lifetime any form of sexual abuse both genders

Lifetime any form of sexual abuse in males

Lifetime any form of sexual abuse in females

Childhood sexual abuse occurring before 16 years of age in women

Childhood sexual abuse occurring before 16 years of age in men

Prevalence

$2 \%$

$6 \%$

$17 \%$

$49 \%$

Lifetime sexual abuse by family

Sexual abuse by nonfamily members

Lifetime prevalence of sexual abuse by both family and nonfamily members

Lifetime any form of sexual abuse

Lifetime sexual abuse by family

Lifetime sexual abuse by nonfamily member

Lifetime sexual abuse by both family and nonfamily members

Lifetime any form of sexual abuse

At least one type of

maltreatment in childhood

Childhood neglect

Childhood emotional abuse

Childhood sexual abuse

Childhood physical abuse

Childhood sexual and

physical abuse

Childhood physical abuse before age 13 in males

Childhood sexual abuse before age 13 in males

Childhood physical abuse before age 13 in females

Childhood sexual abuse before age 13 in females

Childhood physical abuse before age 13 in both males and females males

Childhood sexual abuse before age 13 in both males and females
$7 \%$

$2 \%$ 
Table 1 Prevalence of childhood abuse and neglect in American Indians/Alaska natives, by year of study (Continued)

\begin{tabular}{|c|c|c|c|c|}
\hline & & Northern Plains tribes & $\begin{array}{l}\text { Childhood physical abuse } \\
\text { before age } 13 \text { in males }\end{array}$ & $7 \%$ \\
\hline & & \multirow{5}{*}{$\begin{array}{l}1,638 \text { Northern Plains tribal } \\
\text { members age } 15-54(3,084 \\
\text { Al/AN participants total) }\end{array}$} & Childhood sexual abuse & $1 \%$ \\
\hline & & & $\begin{array}{l}\text { Childhood physical abuse } \\
\text { before age } 13 \text { in females }\end{array}$ & $9 \%$ \\
\hline & & & $\begin{array}{l}\text { Childhood sexual abuse } \\
\text { before age } 13 \text { in females }\end{array}$ & $7 \%$ \\
\hline & & & $\begin{array}{l}\text { Childhood physical abuse } \\
\text { before age } 13 \text { in both } \\
\text { males and females }\end{array}$ & $8 \%$ \\
\hline & & & $\begin{array}{l}\text { Childhood sexual abuse } \\
\text { before age } 13 \text { in both } \\
\text { males and females }\end{array}$ & $4 \%$ \\
\hline \multirow[t]{3}{*}{ Hanson et al. 2006} & \multirow{3}{*}{$\begin{array}{l}\text { U.S. National household probability } \\
\text { sample of 12-17 year olds with } \\
\text { self-report survey }\end{array}$} & \multirow[t]{3}{*}{$139 \mathrm{Al} / \mathrm{AN}$ adolescents } & $\begin{array}{l}\text { Lifetime physically abusive } \\
\text { punishment by caretakers }\end{array}$ & $15 \%$ \\
\hline & & & $\begin{array}{l}\text { Lifetime intrafamilial } \\
\text { sexual abuse }\end{array}$ & $4 \%$ \\
\hline & & & $\begin{array}{l}\text { Lifetime extrafamilial } \\
\text { sexual abuse }\end{array}$ & $11 \%$ \\
\hline \multirow[t]{3}{*}{ Saylors and Daliparthy 2006} & \multirow{3}{*}{$\begin{array}{l}\text { Residential and outpatient substance } \\
\text { abuse treatment settings in urban } \\
\text { Oakland and San Francisco, California; } \\
\text { self-report survey }\end{array}$} & \multirow{3}{*}{$\begin{array}{l}283 \mathrm{Al} / \mathrm{AN} \text { women in } \\
\text { treatment }\end{array}$} & Childhood sexual abuse & $56 \%$ \\
\hline & & & First incident at ages 1-5 & $37 \%$ \\
\hline & & & First incident at ages 6-10 & $37 \%$ \\
\hline \multirow[t]{4}{*}{ de Ravello et al. 2008} & \multirow{4}{*}{$\begin{array}{l}\text { New Mexico prison system; } \\
\text { self-report survey }\end{array}$} & \multirow{4}{*}{$\begin{array}{l}36 \mathrm{Al} / \mathrm{AN} \text { incarcerated } \\
\text { women age } 20-60 \text { years }\end{array}$} & Childhood sexual abuse & $53 \%$ \\
\hline & & & Childhood physical abuse & $42 \%$ \\
\hline & & & $\begin{array}{l}\text { Childhood physical and } \\
\text { sexual abuse }\end{array}$ & $33 \%$ \\
\hline & & & Childhood physical neglect & $22 \%$ \\
\hline Hawkins et al. 2010 & $\begin{array}{l}\text { U.S. National household probability } \\
\text { sample of } 12-17 \text { year olds with } \\
\text { self-report survey }\end{array}$ & $86 \mathrm{Al} / \mathrm{AN}$ adolescents & $\begin{array}{l}\text { Lifetime physical abuse } \\
\text { by caretakers }\end{array}$ & $15 \%$ \\
\hline Welch and Bonner 2013 & $\begin{array}{l}\text { Oklahoma death review board files of } \\
\text { fatalities attributed to child neglect; } \\
\text { administrative data }\end{array}$ & $47 \mathrm{Al} / \mathrm{AN}$ child death cases & Fatality due to neglect & $13 \%$ \\
\hline
\end{tabular}

Abbreviation: Al/AN American Indian/Alaska Native.

abuse, with approximately $90 \%$ of the women neglected in childhood also experiencing physical, emotional, or sexual abuse. In another sample of $36 \mathrm{AI} / \mathrm{AN}$ incarcerated women, $42 \%$ reported that they were physically abused by family members, with 33\% reporting both sexual and physical abuse by family members or loved ones (de Ravello et al. 2008). However, one relatively large study involving a Southwestern tribe and two Northern Plains tribes reported childhood physical abuse prevalence ranging from $7 \%$ to $9 \%$, a figure much lower than other studies (Libby et al. 2005).

Reports of childhood sexual abuse among AI/AN populations are common. Seventeen percent of AI/AN adolescents in Minnesota schools reported at least one instance of childhood sexual abuse (Saewyc et al. 2003). Forty-nine percent of women and $14 \%$ of men in a Southwestern tribe reported experiences of childhood sexual abuse (Robin et al. 1997). In de Ravello et al.'s (2008) sample of 36 incarcerated AI/AN women, $53 \%$ were sexually abused by family members or loved ones. Libby et al. (2005)'s study of the Southwestern and Northern Plains tribes found sexual abuse prevalence to range from $1 \%$ to $8 \%$.

In another study of women receiving treatment for substance use and mental illness in an urban area, abuse started early, with $37 \%$ of women reporting sexual abuse beginning at ages $1-5$ years and another $37 \%$ reporting first experiences at ages 6-10 years (Saylors and Daliparthy 2006). In a state-wide study of school-based adolescents, $\mathrm{AI} / \mathrm{AN}$ respondents were 1.8 times more likely than white respondents to report childhood sexual abuse (Lodico et al. 1996). The same study showed that $17 \%$ of $\mathrm{AI} / \mathrm{AN}$ students, compared to $9 \%$ of white students, reported childhood sexual abuse.

\section{Prevalence of violence against women}

Violence against women encompasses both intimate partner violence (IPV) and sexual violence (World Health 
Organization 2013). While rape, forced sex, sexual violence, and sexual abuse have distinct definitions, our discussion of sexual violence covers all of these types of violence. Prevalence estimates for each type are presented as described within individual studies. The prevalence of VAW among $\mathrm{AI} / \mathrm{AN}$ is among the highest for all races/ethnicities, second only to multiracial women. In the nationally representative National Intimate Partner and Sexual Violence Survey (NISVS), 27\% of AI/AN women reported lifetime rape, higher than prevalence for black (22\%), white (19\%), and Hispanic (15\%) women, though lower than multiracial (34\%) women (Black et al. 2011) (Table 2). Seventeen percent of $\mathrm{AI} / \mathrm{AN}$ women report that their first sexual encounter was forced (Rutman et al. 2012) compared with $10 \%$ of the general American female population in a national survey (Gavin et al. 2009). In NISVS, $46 \%$ of AI/AN reported lifetime physical assault by intimate partner, also higher than prevalence for black (41\%), white (32\%), and Hispanic (35\%) women, though lower than multiracial (50\%) women (Black et al. 2011).

Studies conducted among various tribal communities, urban $\mathrm{AI} / \mathrm{AN}$ populations, and health care facilities serving $\mathrm{AI} / \mathrm{AN}$ provide evidence to support the high prevalence of lifetime VAW reported in NISVS. Lifetime prevalence of rape ranged from 4\%-29\% among women from six geographically diverse tribes in Yuan et al's (2006) Ten Tribes study to $48 \%$ among AI/AN women in New York City (Evans-Campbell et al. 2006). Among young women attending boarding school for at-risk $\mathrm{AI} / \mathrm{AN}, 20 \%$ reported forced sex (Scott and Langhorne 2012), and lifetime prevalence of sexual abuse among women living on reservations in California was 34\% (Ehlers et al. 2013). Lifetime prevalence of sexual violence in intimate partner relationships ranged from $12 \%$ among women in IHS health care (Fairchild et al. 1998) to 29\% among women in a Southwestern tribe (Robin et al. 1998). Lifetime physical assault by an intimate partner ranged from $29 \%$ among $\mathrm{AI} / \mathrm{AN}$ women living on a reservation in the Southwest (Manson et al. 2005) to 79\% among women in a Southwestern tribe (Robin et al. 1998) with several estimates between 30-40\% (Fairchild et al. 1998; Simoni et al. 2004; Manson et al. 2005). Lifetime prevalence of any kind of IPV is consistently high across studies, ranging from $40 \%$ among AI/AN women in New York City (Evans-Campbell et al. 2006) to 91\% among married women in a Southwestern tribe (Robin et al. 1998), with most estimates greater than 50\% (Fairchild et al. 1998; Bohn 2003; Malcoe et al. 2004; Mylant and Mann 2008; Duran et al. 2009; Wood and Magen 2009).

Prevalence estimates for recent experiences of IPV vary but are as high as 60\%. Physical abuse in the past year was reported by $3 \%$ of women living on Montana reservations (Harwell et al. 2003), 14\% of women presenting for care at an IHS health facility (Fairchild et al. 1998), and 37\% of pregnant women in a Northwest city (Curry 1998). Among pregnant women receiving care at a Midwestern Indian clinic, $60 \%$ reported physical assault by their current partner (Bohn 2003). Sexual abuse in the past year was reported by $3 \%$ of women receiving services at a WIC clinic (Malcoe et al. 2004), 9\% of currently pregnant women (Curry 1998), and 23\% of teenage mothers (Mylant and Mann 2008).

$\mathrm{IPV}$ is common among $\mathrm{AI} / \mathrm{AN}$ women during pregnancy. In several studies, one in three $\mathrm{AI} / \mathrm{AN}$ women report IPV in pregnancy (Kvinge et al. 1998; Robin et al. 1998; Bohn 2002) with estimates ranging from $9 \%$ among $\mathrm{AI} / \mathrm{AN}$ women pregnant in the last year (Malcoe et al. 2004) to $38 \%$ among teenage AI/AN mothers (Mylant and Mann 2008). In one survey, $6 \%$ of currently pregnant women reported that their partner had threatened to kill them or their baby (Bohn 2002).

Weapons are more frequently associated with IPV incidents among AI/AN women than among the general population of American women. Among Alaska Native women, $19 \%$ were threatened with a gun and $12 \%$ were threatened with a knife in their lifetimes (Wood and Magen 2009). Among $\mathrm{AI} / \mathrm{AN}$ women attending a WIC clinic in Oklahoma, $11 \%$ of women had been threatened with a knife or gun (Malcoe et al. 2004). This is in comparison with $6 \%$ of the general population of American women who were threatened with a gun and $6 \%$ who were threatened with a knife (Tjaden and Thoennes 2000). Injuries perpetrated by partners were common among women attending WIC clinics (40\%; Malcoe et al. 2004) and married women in a Southwestern Tribe (46\%\%; Robin et al. 1998).

Rates of femicide in the AI/AN population are also very high. The rate of domestic violence homicide in New Mexico from 1990-1993 among AI/AN women was 4.9/ 100,000 women, which was significantly higher than the rates for Hispanics $(1.7 / 100,000)$ and non-Hispanic whites $(1.8 / 100,000)$ (Arbuckle et al. 1996). Firearms were used twice as often in domestic violence homicides compared to homicides not related to domestic violence (Arbuckle et al. 1996).

\section{Prevalence of elder abuse}

Variation in definition and terminology is a challenge in elder abuse research (National Research Council 2003). The Research Council defines elder abuse as "any knowing, intentional, or negligent act by a caregiver or any other person that causes harm or a serious risk of harm to a vulnerable adult." This paper does not confine itself to a particular definition of abuse, and uses "elder abuse" to refer to various kinds of mistreatment, exploitation and neglect. Estimates of elder abuse prevalence are widely variable in the few studies that have explored this issue. Drawing on diverse studies of AI/AN populations, Buchwald et al. (2000) found prevalence estimates of abuse ranging from $2 \%$ to $46 \%$ among AI/AN populations (Minton and Soule 1990; John 1995 in Buchwald et al. 2000) (Table 3). In an 
Table 2 Prevalence of violence against women among American Indians/Alaska natives, by year of study

\begin{tabular}{|c|c|c|c|c|}
\hline First author year & Population and data source & Sample size & Measure & Prevalence \\
\hline \multirow[t]{3}{*}{ Curry 1998} & \multirow{3}{*}{$\begin{array}{l}\text { Prenatal clinics in a Northwest city; } \\
\text { clinic-based sample with } \\
\text { self-report survey }\end{array}$} & \multirow{3}{*}{$\begin{array}{l}57 \mathrm{Al} / \mathrm{AN} \\
\text { women }\end{array}$} & Past year physical IPV & $37 \%$ \\
\hline & & & Past year sexual IPV & $7 \%$ \\
\hline & & & IPV in pregnancy & $12 \%$ \\
\hline \multirow[t]{6}{*}{ Fairchild et al. 1998} & Indian health service facility on a Navajo & $\begin{array}{l}341 \mathrm{Al} / \mathrm{AN} \\
\text { women }\end{array}$ & Lifetime IPV & $53 \%$ \\
\hline & \multirow{5}{*}{$\begin{array}{l}\text { Reservation; clinic-based sample } \\
\text { with self-report survey }\end{array}$} & & Lifetime physical IPV & $42 \%$ \\
\hline & & & Lifetime sexual IPV & $12 \%$ \\
\hline & & & Past year IPV & $16 \%$ \\
\hline & & & Past year physical IPV & $14 \%$ \\
\hline & & & Past year sexual IPV & $4 \%$ \\
\hline Kvigne et al. 1998 & $\begin{array}{l}\text { Pregnant women from a Northern plains } \\
\text { tribe; clinic-based sample with } \\
\text { self-report survey }\end{array}$ & $\begin{array}{l}177 \mathrm{Al} / \mathrm{AN} \\
\text { women }\end{array}$ & IPV in pregnancy & $30 \%$ \\
\hline \multirow[t]{6}{*}{ Robin et al. 1998} & \multirow{6}{*}{$\begin{array}{l}\text { Southwestern tribe; referral-based } \\
\text { sampling with self-report survey }\end{array}$} & 56 married & Lifetime IPV & $91 \%$ \\
\hline & & \multirow[t]{5}{*}{ Al/AN women } & Lifetime physical IPV & $79 \%$ \\
\hline & & & Lifetime sexual IPV & $29 \%$ \\
\hline & & & Past year IPV & $31 \%$ \\
\hline & & & IPV in pregnancy & $34 \%$ \\
\hline & & & $\begin{array}{l}\text { IPV injuries requiring } \\
\text { medical attention }\end{array}$ & $46 \%$ \\
\hline \multirow[t]{2}{*}{ Bohn 2002} & \multirow{2}{*}{$\begin{array}{l}\text { Prenatal clinic in Midwestern city; } \\
\text { clinic-based sample with self-report survey }\end{array}$} & \multirow{2}{*}{$\begin{array}{l}30 \mathrm{Al} / \mathrm{AN} \\
\text { women }\end{array}$} & IPV in pregnancy & $33 \%$ \\
\hline & & & $\begin{array}{l}\text { Threats to kill woman or her baby } \\
\text { in pregnancy }\end{array}$ & $6 \%$ \\
\hline \multirow[t]{4}{*}{ Bohn 2003} & \multirow{4}{*}{$\begin{array}{l}\text { Prenatal clinic in a Midwestern city; } \\
\text { clinic-based sample with self-report survey }\end{array}$} & \multirow{4}{*}{$\begin{array}{l}30 \mathrm{Al} / \mathrm{AN} \\
\text { women }\end{array}$} & Lifetime IPV & $87 \%$ \\
\hline & & & Current partner IPV & $70 \%$ \\
\hline & & & Current partner physical IPV & $60 \%$ \\
\hline & & & Current partner sexual IPV & $17 \%$ \\
\hline Harwell et al. 2003 & $\begin{array}{l}\text { Seven reservations in Montana; random } \\
\text { digit dial sample with self-report survey }\end{array}$ & $\begin{array}{l}588 \mathrm{Al} / \mathrm{AN} \\
\text { women }\end{array}$ & Past year physical IPV & $3 \%$ \\
\hline \multirow[t]{7}{*}{ Malcoe et al. 2004} & \multirow{7}{*}{$\begin{array}{l}\text { WIC clinic in Oklahoma; } \\
\text { clinic-based sample with self-report }\end{array}$} & \multirow{7}{*}{$\begin{array}{l}312 \mathrm{Al} / \mathrm{AN} \\
\text { women }\end{array}$} & Lifetime IPV & $59 \%$ \\
\hline & & & Lifetime sexual IPV & $12 \%$ \\
\hline & & & Lifetime threats with knife/gun & $11 \%$ \\
\hline & & & Past year IPV & $30 \%$ \\
\hline & & & Past year sexual IPV & $3 \%$ \\
\hline & & & IPV in pregnancy, past year & $9 \%$ \\
\hline & & & IPV resulting in injuries & $40 \%$ \\
\hline \multirow[t]{3}{*}{ Simoni et al. 2004} & \multirow{3}{*}{$\begin{array}{l}\text { New York City Al/AN community center } \\
\text { members; self-report survey }\end{array}$} & \multirow{3}{*}{$\begin{array}{l}155 \mathrm{Al} / \mathrm{AN} \\
\text { women }\end{array}$} & Lifetime rape & $34 \%$ \\
\hline & & & Lifetime sexual IPV & $20 \%$ \\
\hline & & & Lifetime physical IPV & $31 \%$ \\
\hline \multirow[t]{2}{*}{ Manson et al. 2005} & \multirow[t]{2}{*}{$\begin{array}{l}2 \text { Northern plains tribes and } 1 \text { Southwestern } \\
\text { tribe; random sampling from tribal rolls } \\
\text { with self-report survey }\end{array}$} & $\begin{array}{l}829 \mathrm{Al} / \mathrm{AN} \\
\text { women in } \\
\text { Southwest }\end{array}$ & Lifetime rape, Southwest & $13 \%$ \\
\hline & & $\begin{array}{l}848 \mathrm{Al} / \mathrm{AN} \\
\text { women in } \\
\text { Northern } \\
\text { plains }\end{array}$ & Lifetime rape, Northern plains & $14 \%$ \\
\hline
\end{tabular}


Table 2 Prevalence of violence against women among American Indians/Alaska natives, by year of study (Continued)

\begin{tabular}{|c|c|c|c|c|}
\hline & & & $\begin{array}{l}\text { Lifetime physical IPV, Northern } \\
\text { plains }\end{array}$ & $31 \%$ \\
\hline \multirow[t]{2}{*}{ Evans-Campbell et al. 2006} & \multirow{2}{*}{$\begin{array}{l}\text { New York City Al/AN; respondent-driven, } \\
\text { chain referral, and targeted sampling } \\
\text { with self-report survey }\end{array}$} & \multirow{2}{*}{$\begin{array}{l}112 \mathrm{Al} / \mathrm{AN} \\
\text { women }\end{array}$} & Lifetime IPV & $40 \%$ \\
\hline & & & Lifetime rape & $48 \%$ \\
\hline Yuan et al. 2006 & $\begin{array}{l}\text { Six tribes in the Southwest, Northwest, Northern } \\
\text { plains, and Northeast; random sample from tribal } \\
\text { rolls with self-report survey }\end{array}$ & $\begin{array}{l}744 \mathrm{Al} / \mathrm{AN} \\
\text { women }\end{array}$ & Lifetime rape & $14 \%$ \\
\hline \multirow[t]{3}{*}{ Mylant and Mann 2008} & \multirow{3}{*}{$\begin{array}{l}\text { Teenage mothers in the Northern plains } \\
\text { participating in pregnancy program; } \\
\text { self-report survey }\end{array}$} & \multirow{3}{*}{$\begin{array}{l}49 \mathrm{Al} / \mathrm{AN} \\
\text { women }\end{array}$} & Lifetime IPV & $61 \%$ \\
\hline & & & IPV in pregnancy & $38 \%$ \\
\hline & & & Past year sexual IPV & $23 \%$ \\
\hline Duran et al. 2009 & $\begin{array}{l}\text { Indian health services clinic in Albuquerque; } \\
\text { clinic-based sample with self-report survey }\end{array}$ & $\begin{array}{l}324 \mathrm{Al} / \mathrm{AN} \\
\text { women }\end{array}$ & Lifetime IPV & $80 \%$ \\
\hline \multirow[t]{4}{*}{ Wood and Magen 2009} & \multirow[t]{4}{*}{ Athabaskan tribe, Alaska; self-report survey } & \multirow{4}{*}{$\begin{array}{l}91 \mathrm{Al} / \mathrm{AN} \\
\text { women }\end{array}$} & Lifetime IPV & $64 \%$ \\
\hline & & & Past year physical IPV & $18 \%$ \\
\hline & & & Lifetime threats with gun & $19 \%$ \\
\hline & & & Lifetime threats with knife & $12 \%$ \\
\hline Rutman et al. 2012 & National survey with self-report & $\begin{array}{l}253 \mathrm{Al} / \mathrm{AN} \\
\text { women }\end{array}$ & Forced first sexual encounter & $17 \%$ \\
\hline \multirow[t]{2}{*}{ Scott and Langhorne 2012} & \multirow{2}{*}{$\begin{array}{l}\text { Boarding school for at-risk Al/AN youth in a } \\
\text { plains state; self-report survey }\end{array}$} & \multirow{2}{*}{$\begin{array}{l}115 \mathrm{Al} / \mathrm{AN} \\
\text { women }\end{array}$} & Lifetime rape & $20 \%$ \\
\hline & & & Lifetime IPV & $70 \%$ \\
\hline Ehlers et al. 2013 & $\begin{array}{l}\text { Eight contiguous reservations in California; } \\
\text { respondent-driven and venue based sampling } \\
\text { with self-report survey }\end{array}$ & $\begin{array}{l}174 \mathrm{Al} / \mathrm{AN} \\
\text { women }\end{array}$ & Lifetime sexual abuse & $34 \%$ \\
\hline \multirow[t]{2}{*}{ Black et al. 2011} & \multirow[t]{2}{*}{ National survey with self-report } & \multirow[t]{2}{*}{ Not reported } & Lifetime rape & $27 \%$ \\
\hline & & & Lifetime physical IPV & $46 \%$ \\
\hline
\end{tabular}

Abbreviations: Al/AN American Indian/Alaska Native, IPV intimate partner violence.

Table 3 Prevalence of elder abuse among American Indians/Alaska natives, by year of study

\begin{tabular}{|c|c|c|c|c|}
\hline First author year & Population and data source & Sample size & Measure & Prevalence \\
\hline \multirow[t]{5}{*}{ Brown 1989} & \multirow[t]{5}{*}{$\begin{array}{l}\text { Navajo tribe, Oljato chapter; randomly } \\
\text { selected tribal members with } \\
\text { self-report survey. }\end{array}$} & \multirow{5}{*}{$\begin{array}{l}\text { Random sample of } \\
37 \text { Al/AN elderly from } \\
\text { a population of } 110 \\
\text { Al/AN elderly }\end{array}$} & $\begin{array}{l}\text { Reported some extent of having } \\
\text { been left alone and neglected } \\
\text { when they needed help }\end{array}$ & $32 \%$ \\
\hline & & & Financially exploited by family members & $22 \%$ \\
\hline & & & Neglected in some way & $46 \%$ \\
\hline & & & Psychologically abused & $22 \%$ \\
\hline & & & Physically abused & $16 \%$ \\
\hline \multirow[t]{2}{*}{ Hudson et al. 1998} & \multirow{2}{*}{$\begin{array}{l}\text { Two tribal groups in North Carolina; } \\
\text { random sample of elderly tribal } \\
\text { members with self-report survey. }\end{array}$} & $200 \mathrm{Al} / \mathrm{AN}$ & Been abused at some time in life (all ages) & $26 \%$ \\
\hline & & 92 over 65-years-old & Abused after the age of 65 & $4 \%$ \\
\hline \multirow[t]{2}{*}{ Buchwald et al. 2000} & \multirow{2}{*}{$\begin{array}{l}\text { Chart review of urban Al/AN in primary } \\
\text { care in King County; clinic-based sample } \\
\text { with medical chart review. }\end{array}$} & $550 \mathrm{Al} / \mathrm{AN}$ elderly & Definite or probable physical abuse & $10 \%$ \\
\hline & & age $\geq 50$ & Suggestive physical abuse & $7 \%$ \\
\hline Minton and Soule 1990 & $\begin{array}{l}216 \text { Alaska natives from two rural } \\
\text { Alaskan villages; randomly selected } \\
\text { tribal members with structured } \\
\text { interview responses. }\end{array}$ & $\begin{array}{l}52 \mathrm{Al} / \mathrm{AN} \text { elderly } \\
\text { age } \geq 55\end{array}$ & Reported sadness as a result of victimization & $11 \%$ \\
\hline
\end{tabular}


analysis of 550 medical charts of urban AI/AN, Buchwald et al. (2000) found 10\% prevalence of probable or definite physical abuse. This was similar to rates of physical abuse found in several smaller studies of AI/AN elders: 11\% of Alaska Natives (Minton and Soule 1990), 16\% of Navajos (Brown 1989), and 19\% of Northern Cheyennes (Cheyenne 1993 in Buchwald et al. 2000). In a cross-cultural study of the occurrence of elder abuse among seven cultural groups, Hudson et al. (1998) found that 4\% of AI/AN surveyed reported abuse occurring after age 65 . This rate was lower than for other racial groups, although the experience of abuse over the lifetime was highest for AI/AN (26\%).

Despite limited data on prevalence, tribal leaders express significant concern about elder abuse (National Indian Council on Aging 2004; Brown 1989; Maxwell and Maxwell 1992). In a survey conducted by the Office of Aging Americans of Tribal Title VI directors, 48\% perceived that elder neglect occurred often and 39\% that psychological or verbal abuse occurred often. This abuse was perceived to occur most often at the hand of spouses/partners and other family members (Jackson and Sappier 2005).

Though there is a high variability of prevalence estimates, it is clear that when elder abuse does occur, it is rarely officially reported. Buchwald et al. (2000) found that only $31 \%$ of definite cases of abuse of elderly AI/AN were reported to authorities. This low rate of reporting is consistent with rates of reporting in other elderly populations in the United States. The National Elder Abuse Incidence Study estimated that only $18 \%$ of cases of elder abuse and neglect occurring in domestic settings are reported to adult services (American Public Human Services Association 1998).

\section{Risk factors for interpersonal violence}

Many of the risk factors for interpersonal violence identified among $\mathrm{AI} / \mathrm{AN}$ are not unique to this population. $\mathrm{AI} / \mathrm{AN}$ risk factors for child abuse and neglect, such as non-married parental status, parental substance abuse, parental history of abuse, parental unemployment, greater number of children in the home, low SES, disabilities in the child, and female gender, are also identified risk factors in other populations (reviewed in Putnam 2003; Sedlak et al. 2010). Low income, low educational attainment, unemployment, younger age, non-married status, childhood abuse, and alcohol use are consistent risk factors for VAW in AI/AN and other populations (reviewed in Capaldi et al. 2012). Risk factors for violence against the elderly include dementia and social isolation in the victims and mental disorders and alcohol misuse among perpetrators as noted in studies of AI/AN and other racial/ethnic groups (reviewed in Lachs and Pillemer 2004).

\section{Common risk factors across the life course}

A number of factors have been identified that increase the risk of abuse and neglect in AI/AN at every stage of life.
Child abuse and VAW have several common risk factors including non-married partnership, female gender of the victim, and substance abuse by the perpetrator (DeBruyn et al. 1992; Horejsi et al. 1992; Nelson et al. 1996; Piasecki et al. 1989; Robin et al. 1997; White and Cornely 1981; Malcoe et al. 2004; Yuan et al. 2006; Robin et al. 1998). While the exact mechanism between alcohol/substance use and perpetration of child neglect/abuse/VAW is unclear, several hypotheses have been suggested (Walsh et al. 2003; Kunitz et al. 1998). Alcohol and other drugs impair mental functioning, judgment, and protective tendencies of users by suppressing brain centers that inhibit socially unacceptable behaviors, leading to perpetration of VAW and child abuse (Goldman et al. 2003; Walsh et al. 2003; Kunitz et al. 1998; Yuan et al. 2006). Caregivers and partners with severe substance dependence may also experience economic difficulties secondary to their alcohol/substance use, compromising their ability to provide for those under their care (Goldman et al. 2003).

Researchers have also proposed societal factors that may increase the prevalence of these risk factors, especially with respect to substance abuse (DeBruyn et al. 2001). Important sociocultural contexts that might affect this include high rates of unemployment and poverty, governmental oppression, racism, under-education, erosion of cultural and traditional lifestyles, and widening chasms between generations (BigFoot and Schmidt 2010; Cross et al. 2000; DeBruyn et al. 2001; DeBruyn et al. 1992; Fischler 1985; Fox 2003; Nelson et al. 1996). Lack of resources, including low income and unemployment, are also common risk factors for perpetration of child and elder abuse and VAW across populations (Maxwell and Maxwell 1992; Malcoe et al. 2004).

\section{Risk factors of childhood abuse}

Several individual and interpersonal risk factors for childhood abuse and neglect have been identified. Certain family structure factors increase the likelihood of child maltreatment among AI/AN, including divorce, teenage parenthood, having children outside of marriage, and single parenthood (DeBruyn et al. 1992; Horejsi et al. 1992; Piasecki et al. 1989; White and Cornely 1981). Other risk factors for experiencing child abuse and neglect include children switching homes (DeBruyn et al. 1992), having multiple men associated with the household (Nelson et al. 1996), stressful life events in the household (Nelson et al. 1996), and having a greater number of children in the household (Horejsi et al. 1992; Nelson et al. 1996; White and Cornely 1981). The presence of psychiatric problems in the caregiver (Nelson et al. 1996), caregiver criminal records (DeBruyn et al. 1992; Lujan et al. 1989; Nelson et al. 1996), and/or of childhood abuse/domestic violence in caregivers' lives (Berlin 1987; Cross et al. 2000; DeBruyn et al. 1992; Fernandez 1987; Horejsi et al. 1992; Lujan et al. 1989; Mannes 1993) are risk factors for perpetrating abuse 
and neglect. Although child disability is associated with maltreatment, the direction of the effect in $\mathrm{AI} / \mathrm{AN}$ remains unclear (DeBruyn et al. 1992; Fischler 1985; U.S. Dept of Health and Human Services 2010).

\section{Risk factors of violence against women}

Women experiencing childhood sexual or physical abuse are also more likely to experience physical and sexual assault in adulthood (Bohn 2003; Yuan et al. 2006). Exposure to maltreatment in childhood is a risk factor for alcohol and substance dependence and other mental disorders later in life for $\mathrm{AI} / \mathrm{AN}$ women (de Ravello et al. 2008; Duran et al. 2004; Koss et al. 2003). The elevated rates of substance dependence may act as a mediator for increased prevalence of VAW in women with history of child abuse and neglect.

Alcohol use by both victims and perpetrators has been identified as a risk factor for VAW. Lifetime alcohol dependence was a risk factor for both physical and sexual assault among women in the Ten Tribes study (Yuan et al. 2006). Seventy-four percent of IPV in a Southwestern tribe involved alcohol use by either the perpetrator or the victim (Robin et al. 1998). Alcohol or drug use immediately prior to death was also common (54\%) among femicide victims in New Mexico in the early 1990s (Arbuckle et al. 1996).

Several demographic factors are associated with VAW among AI/AN. For example, lower educational attainment and unemployment among women have been associated with lifetime experiences of physical assault (Harwell et al. 2003). Socioeconomic status is also an important factor; among women attending a WIC clinic, women with low socioeconomic SES (defined as living at or below $50 \%$ of the poverty line, receiving other government assistance, or having a partner with less than a high school education) had a past year IPV prevalence of $43 \%$ compared with $10 \%$ among women receiving services at WIC who did not meet the low SES criteria (Malcoe et al. 2004) (Table 4). Similarly, Navajo women living in a household that received government assistance had twice the odds of experiencing IPV in the past year (Fairchild et al. 1998). Partner's lower educational attainment and unemployment were also associated with past year IPV in bivariable but not multivariable analyses, after adjusting for low SES among women attending a WIC clinic (Malcoe et al. 2004). Younger age (Fairchild et al. 1998; Harwell et al. 2003; Malcoe et al. 2004) and being separated/divorced or cohabiting with a partner were also associated with past year IPV in several studies (Malcoe et al. 2004; Yuan et al. 2006). Pregnancy is also a period of vulnerability to VAW (Kvinge et al. 1998; Robin et al. 1998; Bohn 2002; Malcoe et al. 2004; Mylant and Mann 2008).

\section{Risk factors of elder abuse}

Risk factors for elder abuse in $\mathrm{AI} / \mathrm{AN}$ populations include gender, disability, and pace of worsening cognitive impairment (Lachs et al. 1994, 1997), and have been suggested to include poverty and a variety of its concomitants: poor health and high rates of illness; frequent loss and trauma; high rates of mental health issues; physical disability; drug and alcohol abuse, and others (Carson 1995). Dependency and inter-dependency among elderly AI/AN and their adult children is common, and among urban AI/AN elders, Buchwald et al. (2000) found significant associations between physical abuse and younger age, female sex, current depression, and dependence on others for food. However, among elderly Navajo, Brown (1989) noted a relationship between abuse and elders having an income.

In the most comprehensive ethnographic study conducted on elder abuse, Maxwell and Maxwell (1992) found that caregiver characteristics, specifically isolation and lack of access to resources, were related to abuse. They conducted comparative work in two Plains tribes, taking a resource-based approach to understanding the contexts in which abuse occurs. They found that sexual abuse was limited to the more isolated and resource-poor reservation, and that rates of abuse overall were also higher at this site, with intentional abuse occurring more frequently on the resource-poor reservation. In a survey in a Plains community, Maxwell and Maxwell (1992) found that the caregivers who abused tended to be younger and to live with their elders. In a survey of a Navajo community, Brown (1989) found that elder abuse was associated especially with caregivers with personal problems, and for elders, a suddenness of onset of dependence on family, elders having mental problems, and family crises as a result of providing care suddenly, for which they were not prepared.

\section{Prevalence of risk factors among Al/AN}

While AI/AN share many of the same risk factors for interpersonal violence as other populations, AI/AN have a much higher prevalence of these risk factors. The AI/AN population has a different demographic profile than the general U.S. population, which includes a higher prevalence of several factors associated with interpersonal violence. Birth rates are higher among young $\mathrm{AI} / \mathrm{AN}$ women than for young women overall (DeVoe and Darling-Churchill 2008), and $\mathrm{AI} / \mathrm{AN}$ women were more likely to have given birth during the last year than non-Hispanic Whites (U.S. Census Bureau 2004). AI/AN people are also more likely to be divorced or never married than non-Hispanic Whites. In 2004, 42\% of AI/AN aged 15 or older were married, compared to $57 \%$ of non-Hispanic Whites (U.S. Census Bureau 2004).

Economic disadvantage is high among AI/AN populations. The AI/AN poverty rate $(26 \%)$ is twice the national rate, and $\mathrm{AI} / \mathrm{AN}$ fail to complete high school at a higher 
Table 4 Risk factors for interpersonal violence in American Indian/Alaska native children, women, and elders, by violence type

\begin{tabular}{|c|c|c|}
\hline First author year & Population & Sample size \\
\hline \multicolumn{3}{|l|}{ Childhood abuse } \\
\hline \multirow[t]{2}{*}{$\begin{array}{l}\text { White and Cornely } \\
1981\end{array}$} & \multirow[t]{2}{*}{$\begin{array}{l}\text { Records Navajo children } \\
<9 \text { years old }\end{array}$} & $\begin{array}{l}365 \text { abused and/or } \\
\text { neglected Al/AN } \\
\text { children }\end{array}$ \\
\hline & & $\begin{array}{l}867 \text { comparison } \\
\text { Al/AN children }\end{array}$ \\
\hline Lujan et al. 1989 & $\begin{array}{l}\text { Southwestern Indian health } \\
\text { service hospital }\end{array}$ & $\begin{array}{l}117 \text { medical records } \\
\text { of abused and/or } \\
\text { neglected Al/AN } \\
\text { children ages 1-21 }\end{array}$ \\
\hline \multirow[t]{2}{*}{ Nelson et al. 1996} & \multirow{2}{*}{$\begin{array}{l}\text { Mesquakie tribe in Tama } \\
\text { Country, lowa; Siletz and } \\
\text { other Northwest tribes in } \\
11 \text {-county area in } \\
\text { Northern Oregon }\end{array}$} & $\begin{array}{l}39 \text { neglecting } \\
\text { Al/AN families }\end{array}$ \\
\hline & & $\begin{array}{l}38 \text { comparison } \\
\text { Al/AN families }\end{array}$ \\
\hline
\end{tabular}

Risk factor

Unmarried parents

Number of children in household

Alcohol abuse by caretaker

History of abuse or neglect in caretaker

Disability in child

Mother under 19 years of age at first birth

More than 1 father associated with

household

Number of children in household

Parents separated or divorced

Substance abuse in caretaker

Criminal charges on caretaker's record

Caretaker has or is receiving psychiatric treatment

Violence against women

Arbuckle et al. 1996

Female homicide victims in $33 \mathrm{Al} / \mathrm{AN}$ women New Mexico

Fairchild et al. 1998

Indian health service facility $341 \mathrm{Al} / \mathrm{AN}$ women on a Navajo reservation

Robin et al. 1998

Southwestern tribe

56 married $\mathrm{Al} / \mathrm{AN}$ women

Bohn 2003

Clinic in a Midwestern city

Seven reservations in

$30 \mathrm{Al} / \mathrm{AN}$ women

Harwell et al. 2003 Montana

$588 \mathrm{Al} / \mathrm{AN}$ women

Malcoe et al. 2004

WIC clinic in Oklahoma

312 Al/AN women

Yuan et al. 2006

Six tribes in the Southwest, $744 \mathrm{Al} / \mathrm{AN}$ women Northwest, Northern plains,

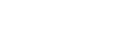

(1)

Alcohol or drug use by victim

Receiving government assistance

Age (under 40)

Alcohol use by either perpetrator or victim

Childhood abuse

Age (under 45)
Low SES (living at or below 50\% poverty line; receiving government assistance; or partner with $<$ HS education)

$\begin{array}{ll}\text { Age (under 32) } & \text { Past year IPV } \\ \text { Separation/divorce } & \text { Past year IPV } \\ \text { Alcohol dependence } & \text { Physical assault } \\ & \text { Sexual assault } \\ \text { Cohabitation } & \text { Physical assault } \\ & \text { Sexual assault } \\ \text { Separation/divorce } & \text { Physical assault } \\ & \text { Sexual assault } \\ \text { Childhood sexual abuse } & \text { Sexual assault }\end{array}$

Elder abuse

Brown 1989

One Navajo tribe, Oljato chapter (110 total elders)

Random sample of

37 elderly and one family member of each elder

Suddenness of onset of dependence

on family

Family perception of dependency

Mental condition less than normal, as perceived by family

\section{Outcome}

Abuse or neglect

Abuse or neglect

Abuse or neglect

Abuse or neglect

Abuse or neglect

Neglect

Neglect

Neglect

Neglect

Neglect

Neglect

Neglect

Homicide by partner

Current IPV

Current IPV

Lifetime IPV

Adult abuse

Past year physical IPV

Past year IPV

Abuse overall

Abuse overall

Neglect

Abuse overall 


\begin{tabular}{|c|c|c|c|c|}
\hline $\begin{array}{l}\text { Maxwell and Maxwell } \\
1992\end{array}$ & 2 Plains Indians tribes & $\begin{array}{l}\text { Community-wide } \\
\text { ethnographic study }\end{array}$ & $\begin{array}{l}\text { Caregivers who abused tended to be } \\
\text { younger and live with their elders; abuse } \\
\text { was more common among less wealthy tribe }\end{array}$ & $\mathrm{N} / \mathrm{A}$ \\
\hline \multirow[t]{5}{*}{ Buchwald et al. 2000} & \multirow{5}{*}{$\begin{array}{l}\text { Chart review of urban } \\
\text { Al/AN (age }>50 \text { ) in primary } \\
\text { care in King County }\end{array}$} & \multirow[t]{5}{*}{$550 \mathrm{Al} / \mathrm{AN}$ elderly } & Younger age & $\begin{array}{l}\text { Definite or probable } \\
\text { physical abuse }\end{array}$ \\
\hline & & & Female & $\begin{array}{l}\text { Definite or probable } \\
\text { physical abuse }\end{array}$ \\
\hline & & & Currently depressed & $\begin{array}{l}\text { Definite or probable } \\
\text { physical abuse }\end{array}$ \\
\hline & & & More likely to depend on & $\begin{array}{l}\text { Definite or probable } \\
\text { physical abuse }\end{array}$ \\
\hline & & & others for food & \\
\hline
\end{tabular}

Abbreviations: Al/AN American Indian/Alaska Native, IPV intimate partner violence, $O R$ odds ratio.

percentage (29\%) than the nation overall (Ogunwole 2006). $\mathrm{AI} / \mathrm{AN}$ unemployment rates were among the highest for all racial/ethnic groups at $15 \%$, compared to $9 \%$ average unemployment rate across all groups (DeVoe and DarlingChurchill 2008).

Studies document that $\mathrm{AI} / \mathrm{AN}$ suffer higher rates of alcohol-related morbidity and mortality than their nonAI/AN counterparts. They are more likely to experience alcohol and illicit drug use disorders (Substance Abuse and Mental Health Services 2010) and die from alcoholattributable deaths (Centers for Disease Control and Prevention 2008). In two national samples of adolescents, AI/AN youth had initiated alcohol and substance use earlier (Wallace et al. 2003), were more likely to have used alcohol or other drugs in the past 30 days (Wallace et al. 2003), and to have alcohol or drug dependence (Wu et al. 2011) than any other racial/ethnic group. Past year binge drinking is $30 \%$ in $\mathrm{AI} / \mathrm{AN}$ adults, higher than any other racial/ethnic group (Substance Abuse and Mental Health Services 2008).

\section{Limitations in existing research}

One of the greatest limitations in interpersonal violence research among $\mathrm{AI} / \mathrm{AN}$ is the scarcity of valid prevalence estimates. To obtain these estimates, sufficient sample sizes and proper sampling frames are necessary. Limited investigation into risk and protective factors for interpersonal violence and lack of a life course perspective in understanding the interconnectedness of interpersonal violence are other important limitations.

A special challenge in researching abuse and neglect in $\mathrm{AI} / \mathrm{AN}$ populations are cultural differences in the definitions of abuse and neglect ascribed by $\mathrm{AI} / \mathrm{AN}$ and non$\mathrm{AI} / \mathrm{AN}$ people. Some researchers in the area caution that neglect may be over-reported by non-AI/AN reporters of child maltreatment due to misunderstanding of the AI/AN communal child rearing system (Earle and Cross 2001; Fox 2003; Fischler 1985). Another challenge to accurate prevalence estimates is that, for cultural reasons, autopsies are rarely conducted on $\mathrm{AI} / \mathrm{AN}$ children who present dead on arrival at the hospital, potentially leading to undercounting of fatal child abuse and neglect.

Measuring the prevalence of elder abuse is complicated by cultural differences in conceptualizing abuse. In the few cross-cultural studies conducted, AI/AN populations tend to rate more behaviors as abusive, and more seriously abusive, than other cultures (Hudson and Carlson 1999). Among Navajo social service providers, those providers with the highest degree of identification with Navajo cultural values had a greater likelihood of perceiving elder abuse and neglect as problematic (Brown 1989). These findings highlight the need to construct valid instruments to measure abuse that permit meaningful comparisons across cultures.

Generalizability across studies of $\mathrm{AI} / \mathrm{AN}$ violence is limited. AI/AN populations are culturally diverse, with more than 560 federally recognized tribes (Bureau of Indian Affairs 2011). They are also geographically diverse, with $60 \%$ of affiliated AI/AN residing off tribal lands (Ogunwole 2006). Additionally, much of the research on violence in $\mathrm{AI} / \mathrm{AN}$ communities is more than a decade old and may not reflect the current experiences interpersonal violence in these populations.

\section{Recommendations for future research}

Given the public health importance of interpersonal violence in $\mathrm{AI} / \mathrm{AN}$ populations, more research is needed in order to develop culturally acceptable prevention and treatment strategies. In particular, new research methods may be necessary to provide important information on prevalence, risk and protective factors, and effectiveness of interventions. More cross-tribal and nationally representative surveys are necessary to understand the larger burden of interpersonal violence among AI/AN. Nationally representative surveys will need to employ oversampling procedures; this will ensure $\mathrm{AI} / \mathrm{AN}$ sample sizes sufficient to produce stable prevalence estimates and to facilitate statistical analysis of 
risk and protective factors. Additionally, long term followup studies are needed to understand the interconnectedness of interpersonal violence across the life course for $\mathrm{AI} / \mathrm{AN}$ populations, including common risk and protective factors and changing vulnerabilities from childhood through later life. Research involving AI/AN populations should be culturally sensitive, mindful of past injustices, and cognizant of the metholodological challenges in measuring interpersonal violence.

Given cultural differences in understandings of child and elder abuse, research in abuse and neglect would benefit from standardization of definitions and measurements. Survey instruments must be culturally sensitive so that meaningful constructs of maltreatment can be documented. Coordination and consistency among researchers working in these areas will be instrumental in creating comprehensive information on abuse among AI/AN populations. There may also be an important role for ethnographic studies in this area.

Conducting research among AI/AN populations requires many special considerations. Tribal leaders should be involved in the establishment of any research projects as tribal institutional review boards or community advisory boards may need to approve research (Katz et al. 2011; Yuan et al. 2006). Confidentiality requirements may extend beyond protecting individual confidentiality to maintaining the confidentiality of the tribe (Katz et al. 2011; Yuan et al. 2006). Research among AI/AN must begin with a plan to relay findings to the community in a timely fashion (Allen et al. 2006). Because data on tribal members' experiences are nested within the cultural context of the tribe, misinterpretation by outsiders may occur. To minimize this, investigators may want to consider including co-researchers from the tribe (Allen et al. 2006), and having any documents intended for wide dissemination first approved by tribal representatives (Holkup et al. 2004). The selection of interviewers for sensitive topics such as abuse must be carefully considered. In the Ten Tribes study, while all interviews were conducted by $\mathrm{AI} / \mathrm{AN}$, tribes that used their own members as interviewers reported lower prevalence of interpersonal violence than tribes using interviewers from other nations (Yuan et al. 2006).

Another potentially useful approach to research involving $\mathrm{AI} / \mathrm{AN}$ is community-based participatory research (CBPR), as it is designed to explicitly acknowledgeand minimize the potential mistrust of outside researchers, a common problem among AI/AN communities. CBPR approaches address many of the concerns noted above by insuring the full participation and inclusion of tribal members in all aspects of the research project (Holkup et al. 2004). CBPR is characterized by working with the community as equal and full partners in the development, implementation, and evaluation of interventions, and the sharing of any knowledge gained with the community (Daley et al. 2010; Holkup et al.
2004). CBPR has been successfully used among AI/AN populations for other health issues (Chester et al. 1999; Daley et al. 2010; Holkup et al. 2007; Johnson et al. 2007; King 1999; Salois et al. 2006) and may be useful for studies on interpersonal violence.

\section{Conclusions}

Anecdotal, survey-based and field study research consistently shows high prevalence of family and partner interpersonal violence in AI/AN populations. Child abuse and neglect, particularly childhood sexual abuse, are highly prevalent among AI/AN, as are experiences of VAW. Elder abuse and neglect are a concern among AI/AN populations, though prevalence estimates are few. While risk factors for violence in this population are not unique, they are also highly prevalent, contributing to the high burden of interpersonal violence in AI/AN communities. Future work among AI/AN should be culturally sensitive, provide valid estimates of prevalence, identify risk and protective factors, and consider the interconnectedness of interpersonal violence across the life course.

\section{Competing interests}

The authors declare that they have no competing interests.

\section{Authors' contributions}

KJS, SMJ, and MFT contributed equally to this manuscript. KJS contributed to design of the review and drafting of the manuscript. SMJ contributed to design of the review and drafting of the manuscript. MFT contributed to design of the review and drafting of the manuscript. RRG contributed to design of the review and critical revision of the manuscript. All authors read and approved the final manuscript.

\section{Acknowledgements}

KJS, SMJ, and MFT were supported by the Susan P. Baker Prize for Injury Prevention in Native Americans.

\section{Author details}

${ }^{1}$ Department of Epidemiology, Mailman School of Public Health, Columbia University, 722 W. 168th St, New York, NY 10032, USA. ²Department of Health Policy and Management, Mailman School of Public Health Columbia University, 722 W. 168th St, New York, NY 10032, USA. ${ }^{3}$ University of Illinois College of Medicine at Rockford, 1601 Parkview Ave, Rockford, IL 61101, USA. ${ }^{4}$ Department of Epidemiology and Biostatistics, School of Medicine, University of California, San Francisco, 3333 California Street, San Francisco, CA 94118, USA. ${ }^{5}$ Philip R. Lee Institute for Health Policy Studies, School of Medicine, University of California, San Francisco, 3333 California Street, San Francisco, CA 94118, USA.

Received: 12 December 2013 Accepted: 25 January 2014 Published: 20 March 2014

\section{References}

Allen J, Mohatt GV, Rasmus SM, Hazel KL, Thomas L, Lindley S. The tools to understand: community as co-researcher on culture-specific protective factors for Alaska Natives. J Prev Interv Community. 2006; 32(1-2):41-59. doi:10.1300/J005v32n01_04.

American Public Human Services Association. The National Elder Abuse Incidence Study. Washington, D.C: The National Elder Abuse Incidence Study; 1998. http://uww.aoa. gov/AoARoot/AoA_Programs/Elder_Rights/Elder_Abuse/docs/ABuseReport_Full. pdf Accessed 11 Jan 2014.

Arbuckle J, Olson L, Howard M, Brillman J, Anctil C, Sklar D. Safe at home? Domestic violence and other homicides among women in New Mexico. Ann Emerg Med. 1996; 27(2):210-5.

Bell J, Lim N. Young once, Indian forever. Am Indian Q. 2005; 29(3):626-50. 
Berlin IN. Effects of changing Native American cultures on child development. J Community Psychol. 1987; 15:299-306.

BigFoot DS, Schmidt SR. Honoring children, mending the circle: cultural adaptation of trauma-focused cognitive-behavioral therapy for American Indian and Alaska native children. J Clin Psychol. 2010; 66(8):847-56.

Black MC, Basile KC, Breiding M, Smith SG, Walters ML, Merrick MT, Chen J, Stevens MR. The National Intimate Partner and Sexual Violence Survey (NISVS): 2010 Summary Report. National Center for Injury Prevention and Control, Centers for Disease Control and Prevention. 2011. http//www.cdc.gov/violenceprevention/ pdf/nisvs_report2010-a.pdf. Accessed 11 Jan 2014

Bohn DK. Lifetime and current abuse, pregnancy risks, and outcomes among Native American women. J Health Care Poor Underserved. 2002; 13(2):184-98,

Bohn DK. Lifetime physical and sexual abuse, substance abuse, depression, and suicide attempts among Native American women. Issues Ment Health Nurs. 2003; 24(3):333-52.

Brave Heart MDLM. The American Indian holocaust: Healing historical unresolved grief. Am Indian Alsk Native Ment Health Res. 1998; 8(2):56-82.

Brave Heart MY. The historical trauma response among natives and its relationship with substance abuse: a Lakota illustration. J Psychoactive Drugs. 2003; 35(1):7-13

Brown AS. A Survey on Elder Abuse at One Native American Tribe. J Elder Abuse Negl. 1989; 1(2):17-38

Buchwald D, Tomita S, Hartman S, Furman R, Dudden M, Manson SM. Physical abuse of urban Native Americans. J Gen Intern Med. 2000; 15(8):562-4.

Bureau of Indian Affairs. What We Do. 2011. Retrieved August 1, 2011, from http:// www.bia.gov/WhatWeDo/index.htm.

Capaldi DM, Knoble NB, Shortt JW, Kim HK. A Systematic Review of Risk Factors for Intimate Partner Violence. Partner Abuse. 2012; 3(2):231-80. doi:10.1891/1946-6560.3.2.231

Carson DK. American Indian elder abuse: Risk and protective factors among the oldest americans. J Elder Abuse Negl. 1995; 7(1):17.

Centers for Disease Control and Prevention. Alcohol-attributable deaths and years of potential life lost among American Indians and Alaska Natives-United States, 2001-2005. MMWR Morb Mortal Wkly Rep. 2008; 57(34):938-41.

Chester B, Mahalish P, Davis J. Mental health needs assessment of off-reservation American Indian people in northern Arizona. Am Indian Alsk Native Ment Health Res. 1999; 8(3):25-40.

Child Abuse Prevention and Treatment Act (CAPTA). Reathorization Act of 2010 as amended by P.L. 111-230. Children's Bureau, Administration on Children, Youth and Families, Administration for Children and Families, U.S. Department of Health and Human Services. 2013. http://www.acf.hhs.gov/sites/default/files/ cb/capta2010.pdf. Accessed 11 Jan 2014.

Cross TL, Simmons D. Child abuse and neglect and American Indians: Overview and Policy Briefing. National Indian Child Welfare Association; 2008. http//childwelfare. ncaiprc.org/documentlibrary/2010/03/CA\&N\%20briefing\%20paper.pdf Accessed 11 Jan 2014.

Cross TL, Earle KA, Simmons D. Child abuse and neglect in Indian Country: Policy issues. Fam Soc. 2000; 81(1):49-58.

Curry MA. The interrelationships between abuse, substance use, and psychosocial stress during pregnancy. J Obstet Gynecol Neonatal Nurs. 1998; 27(6):692-9.

Daley CM, Greiner KA, Nazir N, Daley SM, Solomon CL, Braiuca SL, Smith TE, Choi WS. All Nations Breath of Life: using community-based participatory research to address health disparities in cigarette smoking among American Indians. Ethn Dis. 2010; 20(4):334-8,

de Ravello L, Abeita J, Brown P. Breaking the cycle/mending the hoop: Adverse childhood experience among incarcerated American Indian/Alaska Native women in New Mexico. Health Care Women Int. 2008; 29:300-15.

DeBruyn LM, Lujan CC, May PA. A comparative study of abused and neglected American Indian children in the southwest. Soc Sci Med. 1992; 35(3):305-15.

DeBruyn L, Chino M, Serna P, Fullerton-Gleason L. Child maltreatment in American Indian and Alaska Native communities: integrating culture, history, and public health for intervention and prevention. Child Maltreat. 2001; 6(2):89-102.

Deer S. Toward an indigenous jurisprudence of rape. Kansas J Law Public Policy. 2004; 14:121-54

DeVoe JF, Darling-Churchill KE. Status and trends in the education of American Indians and Alaska Natives: 2008 (NCES 2008-084). Washington DC: National Center for Education Statistics, Institute of Education Sciences, U.S. Department of Education; 2008.

Duran E, Duran B. Native American Postcolonial Psychology. Albany: SUNY Press; 1995.

Duran B, Malcoe LH, Sanders M, Waitzkin H, Skipper B, Yager J. Child maltreatment prevalence and mental disorders outcomes among American Indian women in primary care. Child Abuse Negl. 2004; 28:131-45.
Duran B, Oetzel J, Parker T, Malcoe LH, Lucero J, Jiang Y. Intimate partner violence and alcohol, drug, and mental disorders among American Indian women in primary care. Am Indian Alsk Native Ment Health Res. 2009; 16(2):11-27.

Earle KA, Cross A. Child abuse and neglect among American Indian/Alaska Native children. National Indian Child Welfare Association; 2001. http://muskie.usm.maine. edu/helpkids/rcpdfs/B060041.pdf Accessed 11 Jan 2014.

Ehlers CL, Gizer IR, Gilder DA, Yehuda R. Lifetime history of traumatic events in an American Indian community sample: heritability and relation to substance dependence, affective disorder, conduct disorder and PTSD. J Psychiatr Res. 2013; 47(2):155-61. doi:10.1016/j.jpsychires.2012.10.002.

Evans-Campbell T, Lindhorst T, Huang B, Walters KL. Interpersonal violence in the lives of urban American Indian and Alaska Native women: implications for health, mental health, and help-seeking. Am J Public Health. 2006; 96(8):1416-22. doi:10.2105/A.JP.2004.054213.

Fairchild DG, Fairchild MW, Stoner S. Prevalence of adult domestic violence among women seeking routine care in a Native American health care facility. Am J Public Health. 1998; 88(10):1515-7.

Fernandez R. Evaluating the loss of kinship structures: A case study of North American Indians. Hum Organ. 1987; 46:1-9.

Fischler RS. Child abuse and neglect in American Indian communities. Child Abuse Negl. 1985; 9:95-106.

Fox KA. Collecting data on the abuse and neglect of American Indian children. Child Welfare. 2003; 82(6):707-26.

Gavin L, Mackay AP, Brown K, Harrier S, Ventura SJ, Kann L, Rangel M, Berman S, Dittus P, Liddon N, Markowitz L, Sternberg M, Weinstock H, David-Ferdon C, Ryan G. Sexual and reproductive health of persons aged 10-24 years - United States, 20022007. MMWR Surveill Summ. 2009; 58(6):1-58.

Goldman J, Salus MK, Wolcott D, Kennedy KY. In: Office of Child Abuse and Neglect Department of Health and Human Services, editor. A Coordinated Response to Child Abuse and Neglect: The Foundation for Practice. Washington, DC; 2003.

Greenfeld LA, Smith SK. American Indians and Crime. Bureau of Justice Statistics, Office of Justice Programs, U.S. Department of Justice. 1999. http://www.bjs. gov/content/pub/pdf/aic.pdf. Accessed 11 Jan 2014.

Hanson RF, Self-Brown S, Fricker-Elhai AE, Kilpatrick DG, Saunders BE, Resnick HS. The relations between family environment and violence exposure among youth: findings from the national survey of adolescents. Child Maltreat. 2006; 11(1):3-15. doi:10.1177/1077559505279295.

Harwell TS, Moore KR, Spence MR. Physical violence, intimate partner violence, and emotional abuse among adult American Indian men and women in Montana. Prev Med. 2003; 37(4):297-303.

Hawkins AO, Danielson CK, de Arellano MA, Hanson RF, Ruggiero K, Smith DW, Saunders BE, Kilpatrick DG. Ethnic/racial differences in the prevalence of injurious spanking and other child physical abuse in a National Survey of Adolescents. Child Maltreat. 2010; 15(3):242-9. doi:10.1177/1077559510367938.

Holkup PA, Tripp-Reimer T, Salois EM, Weinert C. Community-based participatory research: an approach to intervention research with a Native American community. Adv Nurs Sci. 2004; 27(3):162-75.

Holkup PA, Salois EM, Tripp-Reimer T, Weinert C. Drawing on wisdom from the past: an elder abuse intervention with tribal communities. Gerontologist. 2007; 47(2):248-54

Horejsi C, Craig BH, Pablo J. Reactions by Native American parents to child protection agencies: cultural and community factors. Child Welfare. 1992; 71(4):329-42.

Hudson MF, Carlson JR. Elder abuse: Its meaning to Caucasians, African-Americans, and Native Americans. In: Tatara T, editor. Understanding Elder Abuse in Minority Populations. Philadelphia: Taylor \& Francis; 1999.

Hudson MF, Armachain WD, Beasley CM, Carlson JR. Elder abuse: two Native American views. Gerontologist. 1998; 38(5):538-48.

Jackson MY, Sappier T. In: Services DoHaH, editor. Elder abuse issues in Indian Country. Washington DC: Administration on Aging, Office for American Indian, Alaskan Native and Native Hawaiian Programs; 2005.

Johnson JL, Gryczynski J, Wiechelt SA. HIV/AIDS, substance abuse, and hepatitis prevention needs of Native Americans living in Baltimore: in their own words. AIDS Educ Prev. 2007; 19(6):531-44. doi:10.1521/aeap.2007.19.6.531.

Katz JR, Martinez T, Paul R. Community-based participatory research and American Indian/Alaska Native nurse practitioners: a partnership to promote adolescent health. J Am Acad Nurse Pract. 2011; 23(6):298-304. doi:10.1111/j.1745-7599. 2011.00613.x.

King J. Denver American Indian mental health needs survey. Am Indian Alsk Native Ment Health Res. 1999; 8(3):1-12. 
Koss MP, Yuan NP, Dightman D, Prince R, Polacca M, Sanderson B, Goldman D. Adverse childhood exposures and alcohol dependence among seven Native American tribes. Am J Prev Med. 2003; 25(3):238-44.

Kunitz SJ, Levy JE, McCloskey J, Gabriel KR. Alcohol dependence and domestic violence as sequelae of abuse and conduct disorder in childhood. Child Abuse Negl. 1998; 22(11):1079-91.

Kvigne VL, Bull LB, Welty TK, Leonardson GR, Lacina L. Relationship of prenatal alcohol use with maternal and prenatal factors in American Indian women. Soc Biol. 1998; 45(3-4):214-22.

Lachs MS, Pillemer K. Elder Abuse. Lancet. 2004; 364:1263-72.

Lachs MS, Berkman L, Fulmer T, Horwitz Rl. A prospective community-based pilot study of risk factors for the investigation of elder mistreatment. J Am Geriatr Soc. 1994; 42(2):169-73

Lachs MS, Williams C, O'Brien S, Hurst L, Horwitz R. Risk factors for reported elder abuse and neglect: a nine-year observational cohort study. Gerontologist. 1997; 37(4):469-74.

Libby AM, Orton HD, Novins DK, Beals J, Manson SM, Al-SUPERPFP Team. Childhood physical and sexual abuse and subsequent depressive and anxiety disorders for two American Indian tribes. Psychol Med. 2005; 35(3):329-40.

Lodico MA, Gruber E, DiClemente RJ. Childhood sexual abuse and coercive sex among school-based adolescents in a midwestern state. J Adolesc Health. 1996; 18:211-7.

Lujan C, DeBruyn LM, May PA, Bird ME. Profile of abused and neglected American Indian children in the Southwest. Child Abuse Negl. 1989; 13(4):449-61.

Luna-Firebaugh EM. Violence against American Indian Women and the ServicesTraining-Officers-Prosecutors Violence Against Indian Women (STOP VAIW) program. Violence Against Women. 2006; 12(2):125-36. doi:10.1177/ 1077801205280932

Malcoe LH, Duran BM, Montgomery JM. Socioeconomic disparities in intimate partner violence against Native American women: a cross-sectional study. BMC Med. 2004; 2:20. doi:10.1186/1741-7015-2-201741-7015-2-20.

Mannes M. Seeking the balance between child protection and family preservation in Indian child welfare. Child Welfare. 1993; 72:141-52.

Manson SM, Beals J, Klein SA, Croy CD. Social epidemiology of trauma among 2 American Indian reservation populations. Am J Public Health. 2005; 95(5):851-9. doi:10.2105/AJPH.2004.054171.

Maxwell EK, Maxwell RJ. Insults to the Body Civil: Mistreatment of Elderly in Two Plains Indian Tribes. J Cross Cult Gerontol. 1992; 7:3-23.

Minton BA, Soule $S$. Two Eskimo villages assess mental health strengths and needs. Am Indian Alsk Native Ment Health Res. 1990; 4(2):7-24.

Mylant M, Mann C. Current sexual trauma among high-risk teen mothers. J Child Adolesc Psychiatr Nurs. 2008; 21(3):164-76. doi:10.1111/j.1744-6171.2008.00148.x.

National Indian Council on Aging for the National Council on Elder Abuse. Preventing and Responding to Abuse of Elders in Indian Country. Washington, DC: National Center on Elder Abuse; 2004.

National Research Council. Panel to Review Risk and Prevalence of Elder Abuse and Neglect. Elder mistreatment: Abuse, neglect, and exploitation in an aging America. Washington, DC: National Academies Press; 2003

Nelson K, Cross T, Landsman M, Tyler M. Native American families and child neglect. Child Youth Sen Rev. 1996; 18(6):505-21.

Ogunwole SU. In: Bureau USC, editor. We the People: American Indians and Alaska Natives in the United States. ; 2006.

Pavkov TW, Travis L, Fox KA, King CB, Cross TL. Tribal youth victimization and delinquency: analysis of Youth Risk Behavior Surveillance Survey data. Cultur Divers Ethnic Minor Psychol. 2010; 16(2):123-34. doi:10.1037/a0018664.

Piasecki JM, Manson SM, Biernoff MP, Hiat AB, Taylor SS, Bechtold DW. Abuse and neglect of American Indian children: findings from a survey of federal providers. Am Indian Alsk Native Ment Health Res. 1989; 3(2):43-62.

Putnam FW. Ten-year research update review: Child sexual abuse. J Am Acad Child Adolesc Psychiatry. 2003; 42(3):269-78

Robin RW, Chester B, Rasmussen JK, Jaranson JM, Goldman D. Prevalence, characteristics, and impact of childhood sexual abuse in a Southwestern American Indian tribe. Child Abuse Negl. 1997; 21(8):769-87.

Robin RW, Chester B, Rasmussen JK. Intimate violence in a southwestern American Indian tribal community. Cult Divers Ment Health. 1998; 4(4):335-44.

Rutman S, Taualii M, Ned D, Tetrick C. Reproductive health and sexual violence among urban American Indian and Alaska Native young women: select findings from the National Survey of Family Growth (2002). Matern Child Health J. 2012; 16(Suppl 2):347-52. doi:10.1007/s10995-012-1100-1.

Saewyc EM, Pettingell S, Magee LL. The prevalence of sexual abuse among adolescents in school. J Sch Nurs. 2003; 19(5):266-72.
Salois EM, Holkup PA, Tripp-Reimer T, Weinert C. Research as Spiritual Covenant West J Nurs Res. 2006; 28:505-25. doi:10.1177/0193945906286809.

Saylors K, Daliparthy N. Violence against Native women in substance abuse treatment. Am Indian Alsk Native Ment Health Res. 2006; 13(1):32-51.

Scott D, Langhorne A. Believing in Native Girls: characteristics from a baseline assessment. Am Indian Alsk Native Ment Health Res. 2012; 19(1):15-36. doi:10.5820/ aian.1901.2012.15.

Sedlak AJ, Mettenburg J, Basena M, Petta I, McPherson K, Greene A, Li S. Fourth National Incidence Study of Child Abuse and Neglect (NIS-4): Report to Congress. Washington, DC: Administration for Children and Families, US Dept of Health and Human Services; 2010

Simoni JM, Sehgal S, Walters KL. Triangle of risk: urban American Indian women's sexual trauma, injection drug use, and HIV sexual risk behaviors. AIDS Behav. 2004; 8(1):33-45

Substance Abuse and Mental Health Services Administration. Results from the 2007 National Survey on Drug Use and Health: National Findings. Rockville, MD: Office of Applied Studies; 2008. NSDUH Series H-34, DHHS Publication No. SMA 08-4343.

Substance Abuse and Mental Health Services Administration. The NSDUH Report: Substance Use among American Indian or Alaska Native Adults. Rockville, MD: Office of Applied Studies; 2010.

Tjaden N, Thoennes N. In: Justice Do, editor. Full report of the prevalence, incidence, and consequences of violence against women. Washington, D.C; 2000. https://www.ncjrs. gov/pdffiles1/nij/183781.pdf Accessed 11 Jan 2014

U.S. Census Bureau, The American Community Survey. American Indians and Alaska Natives 2004. 2004. http://www.census.gov/prod/2007pubs/acs-07.pdf.

US. Department of Health and Human Services. Child Maltreatment 2009: U.S. Department of Health and Human Services, Administration for Children and Families AoC, Youth and Families, Children's Bureau. ; 2010. http://archive.acf.hhs.gov/ programs/cb/pubs/cm09/cm09.pdf Accessed 11 Jan 2014.

Wallace JM Jr, Bachman JG, O'Malley PM, Schulenberg JE, Cooper SM, Johnston LD. Gender and ethnic differences in smoking, drinking and illicit drug use among American 8th, 10th and 12th grade students, 1976-2000. Addiction. 2003; 98(2):225-34

'Walsh C, MacMillan HL, Jamieson E. The relationship between parental substance abuse and child maltreatment: findings from the Ontario Health Supplement. Child Abuse Negl. 2003; 27(12):1409-25.

Welch GL, Bonner BL. Fatal child neglect: Characteristics, causation, and strategies for prevention. Child Abuse Negl. 2013; 37:745-52.

White $\mathrm{R}$, Cornely D. Navajo child abuse and neglect study: A comparison group examination of abuse and neglect of Navajo children. Child Abuse Negl. 1981; 53:175-94.

Wood DS, Magen RH. Intimate partner violence against Athabaskan women residing in interior Alaska: results of a victimization survey. Violence Against Women. 2009: 15(4):497-507. doi:10.1177/1077801208331245.

World Health Organization. World report on violence and health: summany. World Health Organization; 2002. http://www.who.int/violence_injury_prevention/ violence/world_report/en/summary_en.pdf. Accessed 11 Jan 2014.

World Health Organization. Violence Against Women. World Health Organization; 2013. http://www.who.int/mediacentre/factsheets/fs239/en/. Accessed 11 Jan 2014

Wu LT, Woody GE, Yang C, Pan JJ, Blazer DG. Racial/ethnic variations in substancerelated disorders among adolescents in the United States. Arch Gen Psychiatry. 2011; 68(11):1176-85. doi:10.1001/archgenpsychiatry.2011.120.

Yuan NP, Koss MP, Polacca M, Goldman D. Risk factors for physical assault and rape among six Native American tribes. J Interpers Violence. 2006; 21(12):1566-90. doi:10.1177/0886260506294239.

doi:10.1186/2197-1714-1-7

Cite this article as: Sapra et al:: Family and partner interpersonal

violence among American Indians/Alaska Natives. Injury Epidemiology $20141: 7$. 